\title{
HISTORIOGRAPHY
}

\section{The Decision to Use the Bomb: A Historiographical Update*}

J. SAMUEL WALKER

In a powerful and provocative essay published in the New Republic in 1981, Paul Fussell, an English professor and author of the prize-winning The Great War and Modern Memory, challenged views that the atomic bombing of Japan had been immoral, unjustifiable, or unwise. He argued that from the perspective of a combat soldier, which he was in 1945, the use of nuclear weapons was a cause for celebration because it averted the fearful prospect of invading Japan. "When the atom bombs were dropped and news began to circulate that 'Operation Olympic' would not, after all, be necessary, when we learned to our astonishment that we would not be obliged in a few months to rush up the beaches near Tokyo assault-firing while being machine-gunned, mortared, and shelled, for all the practiced phlegm of our tough facades we broke down and cried with relief and joy," he recalled. "We were going to live."

Fussell's broadside, criticizing writers who had never experienced warfare on the front lines and who introduced ambiguity and "genteel ethics" into the discussion of the atomic attacks, should be unpersuasive to historians. One cause for skepticism is, as Martin J. Sherwin remarked, that Fussell argued that "the President made his decision in Washington for the same reasons he (Fussell) celebrated that decision in Europe." An even more important reason for questioning the merits of Fussell's observations is that he cavalierly

*This article expresses the personal views of the author. It does not represent an official position of the U.S. Nuclear Regulatory Commission or any other agency of the federal government. 
ignored a rich and controversial historiography that disproved the basic premise of his essay.

Questions about the wisdom and morality of using the bomb arose shortly after Hiroshima. The central issue in a rather sporadic debate among scholars, journalists, former government officials, and publicists was whether the bomb was necessary to end the war against Japan promptly or whether other means were available to achieve the same goal. The prevailing view, advanced by former policymakers and supported by most scholars, held that the bomb obviated the need for an invasion of Japan, accelerated the conclusion of the war, and saved a vast number of American lives. But several writers, including Norman Cousins and Thomas K. Finletter, P. M. S. Blackett, Carl Marzani, William Appleman Williams, and D. F. Fleming, suggested that the bomb was not essential for a rapid end to the war and/or that its use was dictated more by political than by military considerations. $^{2}$

In the first scholarly treatment of the subject based on extensive research in primary sources, Herbert Feis supplied an authoritative, though not definitive, evaluation of those issues. He declared without equivocation in 1961 that the bomb was not needed to force Japan's surrender "on [American] tcrms within a few months." Feis endorsed the U.S. Strategic Bombing Survey's conclusion that the war would have been over no later than the end of 1945 even without the bomb, Soviet entry into the war, or an invasion of the Japanese islands. But he argued that even though the bomb was not essential to end the war, its use was justified. American policymakers, he maintained, were convinced that dropping the bomb would save "probably tens of thousands" of American lives. Feis insisted that "the impelling reason for the decision to use [the bomb] was military-to end the war victoriously as soon as possible."3

Gar Alperovitz's Atomic Diplomacy, published in 1965, directly challenged Feis's conclusions and triggered a sharply contested

${ }^{1}$ Paul Fussell, "Hiroshima: A Soldier's View," New Republic 185 (22 and 29 August 1981): 26-30; Martin J. Sherwin, "Hiroshima and Modem Memory," Nation 233 (10 October 1981): 329,349-53. A slightly expanded version of Fussell's essay is included in his Thank God for the Alom Bomb (New York, 1988).

${ }^{2}$ For a valuable detailed essay on the literature before 1974 see Barton J. Bernstein, "The Atomic Bomb and American Foreign Policy, 1941-1945: An Historiographical Controversy," Peace and Change 2 (Spring 1974): 1-16. This essay focuses on publications that have appeared since that time.

The onhodox position on the use of the bomb is clearly outlined in Henry L. Stimson and McGeorge Bundy, On Active Service in Peace and War (New York, 1948); Harry S. Tnuman, Memoirs: Year of Decisions (Garden City, 1955); and Samuel Eliot Morison, "Why Japan Surrendered," The Allantic 206 (October 1960): 41-47. For early dissenting views see Norman Cousins and Thomas K. Finletter, "A Beginning for Sanity," Salurday Review of Literature 29 (15 June 1946): 5-9; P. M. S. Blackett, Military and Political Consequences of Alomic Energy (London, 1948); Carl Marzani, We Can Be Friends (New York, 1952); William Appleman Williams, The Tragedy of American Diplomacy (Cleveland, 1959); and D. F. Fleming, The Cold War and Its Origins (Garden City, 1961).

${ }^{3}$ Herbert Feis, Japan Subdued: The Atomic Bomb and the End of the War in the Pacific (Princeton, 1961). 
historiographical dispute. Alperovitz contended that political rather than military considerations were the key to understanding the use of the bomb; he insisted that it was dropped primarily to impress the Soviets rather than to defeat the Japanese. His book received far more attention and stirred far greater discord than earlier works that had argued along the same lines, in part because he drew from recently opened sources to reconstruct events in unprecedented detail, in part because of growing uneasiness about the conduct of U.S. foreign policy in Vietnam, and in part because of the emerging scholarly debate over the origins of the Cold War.

Alperovitz agreed with Feis that the bomb was not needed to end the war in Asia but differed with him about the reasons that it was used. In his view, President Harry S. Truman and his advisers saw the bomb as a diplomatic lever that could be employed to thwart Soviet ambitions in Eastern Europe and Asia. Soon after taking office, Truman reversed Franklin D. Roosevelt's efforts to cooperate with the Soviets by condemning them for their actions in Poland. After learning about the prospects for the bomb, however, he adopted a "strategy of a delayed showdown" in order to avoid a confrontation with the Soviets and postpone the Potsdam meeting until the bomb was tested. If it proved successful, it could not only strengthen the diplomatic position of the United States in opposing Soviet policies in Eastern Europe but also end the war against Japan before the Soviets invaded and gained control of Manchuria.

Alperovitz argued that political considerations, not military ones, explained why the Truman administration did not explore alternatives to using the bomb to end the war, such as investigating the seriousness of Japanese peace initiatives, moderating the demand for unconditional surrender, or waiting for the Soviets to declare war on Japan. He further asserted that the bomb raised the confidence of American policymakers that they could successfully challenge Soviet expansionism in Europe and Asia, and that armed with the bomb, they mounted a "diplomatic offensive" after Hiroshima. In short, Alperovitz emphasized three main themes: the prospect of having the bomb was the guiding factor in the U.S. posture toward the Soviet Union in the spring and summer of 1945; the anticipated impact of the bomb on Soviet-American relations was crucial in motivating the Truman administration to use it; and the monopoly of atomic technology brought about policy shifts by the United States that played an important role in causing the Cold War.4

Alperovitz's "revisionist" thesis provoked a spirited reaction from a diverse array of scholars who agreed on little except that he was wrong. Gabriel Kolko, the most doctrinaire of New Left interpreters of the beginning of the Cold War, did not view use of the bomb as a major policy or moral issue and dismissed it as a factor in causing U.S.-Soviet discord. From a quite different perspective, Thomas T. Hammond, who found it "almost incredible that the United States failed to take fullest advantage of its atomic monopoly in 1945," described Alperovitz's findings as "implausible,

${ }^{4}$ Gar Alperovitz, Alomic Diplomacy: Hiroshima and Potsdam (New York, 1965). 
exaggerated, or unsupported by the evidence." Perhaps the harshest attack came from Robert James Maddox, who, after checking Alperovitz's footnotes, called Atomic Diplomacy a piece of "creative writing." He thought it "disconcerting ... that such a work could have come to be considered a contribution to the historical literature on the period." Despite the criticism, many scholars took Alperovitz's arguments seriously. His book spurred a great deal of scholarly effort that was designed, implicitly or explicitly, to test his hypothesis. ${ }^{5}$

By the mid-1970s, several important new studies, aided by the opening of key primary sources, had discounted parts of Alperovitz's position but substantiated others. Lisle A. Rose defended the Truman administration against some of Alperovitz's criticisms. He disagreed that Truman adopted a "strategy of delay" by postponing the Potsdam Conference in hopes that the bomb would be tested by the time the meeting began. He denied that the United States practiced any form of atomic diplomacy at Potsdam or bombed Hiroshima for political reasons. Despite his generally sympathetic view of Truman, however, Rose condemned the administration for attempting to take advantage of its atomic monopoly after the war to win diplomatic gains from the Soviet Union, and he denounced the destruction of Hiroshima and Nagasaki as "vile acts."6

Martin J. Sherwin found Alperovitz's interpretation more persuasive than did Rose, but he also took issue with some of the key points in Atomic Diplomacy. In A World Destroyed Sherwin stressed that a full understanding of U.S. atomic policies required an examination of Roosevelt's as well as Truman's actions. He showed that from the beginning of the Manhattan Project, senior policymakers viewed the bomb as only a potential weapon and left any decisions about how it would be used for the future. They never seriously questioned whether it would be used at all if it became available. Roosevelt was secretive in his treatment of atomic energy issues and he ruled out sharing information about the bomb project with the Soviet Union. After assuming the presidency, Truman quickly adopted a firmer posture toward the Soviets than Roosevelt had taken, but Sherwin found no evidence of an elaborately planned showdown or "strategy of delay" in dealing with them.

Sherwin argued that the principal motive for using the bomb was to end the war as soon as possible. Policymakers saw no reason to reassess their assumption that the bomb would be dropped once it was ready. Sherwin agreed with Alperovitz that high-level officials viewed the bomb as a political weapon that could provide diplomatic leverage, but he regarded such

${ }^{5}$ Gabriel Kolko, The Politics of War: The World and United States Foreign Policy, 1943-1945 (New York, 1968); Thomas T. Hammond, “'Atomic Diplomacy' Revisited," Orbis 19 (Winter 1976): 1403-28; Rober James Maddox, "Atomic Diplomacy: A Study in Creative Writing," Journal of American History 59 (March 1973): 925-34; idem, The New Left and the Origins of the Cold War (Princeton, 1973); Bemstein, "Atomic Bomb and American Foreign Policy," 10-12.

${ }^{6}$ Lisle A. Rose, Dubious Victory: The United States and the End of World War II (Kent, $\mathrm{OH}, 1973)$. 
considerations as secondary to the military ones. While denying any "diabolical motivations" on the part of the Truman administration, he regretted that it did not seriously weigh alternatives to the bomb. He suggested that modifying the unconditional surrender terms might have made the bombing of Hiroshima unnecessary and submitted that the attack on Nagasaki was indefensible.?

In an article published in 1975, Barton J. Bernstein, addressing Alperovitz's interpretation more directly than Sherwin, arrived at similar conclusions. Bernstein also emphasized the influence and momentum of Roosevelt's legacy in effectively narrowing the options available to Truman in dealing with the bomb. Like his predecessor, Truman assumed that the bomb was a legitimate weapon of war and was unlikely to change longstanding policies without any compelling reason to do so. Bernstein considered five possible altematives to using the bomb to end the war: waiting for Soviet entry into the Far Eastern conflict; demonstrating the power of the bomb by setting off a warning shot in an uninhabited area; mitigating the demand for Japan's unconditional surrender; exploring the proposals of Japanese "peace feelers"; and relying solely on conventional weapons. He argued that each alternative seemed to policymakers to be less desirable, less feasible, or riskier than the atomic bomb option.

Bernstein emphasized that policymakers saw no reason to avoid dropping the bomb. They used it primarily to end the war and save American lives. They hoped the bomb would provide political gains by helping win diplomatic concessions from the Soviets, but this was, in Bernstein's estimation, "a bonus." He concurred with Alperovitz that the Truman administration wielded the bomb as a part of its diplomatic arsenal after the war, which he believed intensified but did not in itself cause the Cold War. Although he accepted parts of Alperovitz's thesis, Bernstein cast doubt on many of the arguments in and the emphasis of Atomic Diplomacy. Oddly enough, for a prominent Cold War revisionist, Bernstein came off in this article as a defender of the Truman administration, at least from much of the criticism that Alperovitz leveled against it. ${ }^{8}$

Other scholars who examined the question of the use of the bomb in the context of the developing Cold War agreed with the major points made by Sherwin and Bernstein. Several major works, in brief discussions of the decision to drop the bomb, supported the thesis that the Truman administration used it primarily for military reasons but also hoped that an additional result would be increased diplomatic power. Thus John Lewis Gaddis, in a book that preceded the appearance of Sherwin's and Bernstein's analyses, and Daniel Yergin and Robert J. Donovan, in books that followed

${ }^{7}$ Martin J. Sherwin, A World Destroyed: The Atomic Bomb and the Grand Alliance (New York, 1975). Sherwin introduced his major arguments in "The Atomic Bomb and the Origins of the Cold War: U.S. Atomic Energy Policy and Diplomacy, 1941-1945," American Historical Review 78 (October 1973): 945-68.

${ }^{8}$ Barton J. Bernstein, "Roosevelt, Truman, and the Atomic Bomb, 1941-1945: A Reinterpretation," Political Science Quarterly 90 (Spring 1975): 23-69. 
thcir publication, largely rejected Alperovitz's specific arguments but still accepted a key part of his overall framework. Gregg Herken concurred that the bomb served both military and diplomatic purposes, and stressed how Truman and Secretary of War Henry L. Stimson carefully weighed its political implications. In a study of James F. Byrnes, the most unabashed proponent of atomic diplomacy, Robert L. Messer took a similar view. While denying Alperovitz's contention that the bomb was a major consideration in American planning for the Potsdam Conference, he criticized Truman and Byrnes for harboring illusions that possession of it "would save China, preserve the Open Door, make the Russians more manageable in Europe, and allow American leaders to dictate their own terms for the peace." 9

Long after its publication, the impact of Alperovitz's Atomic Diplomacy on serious historical writing was apparent. In important ways, it shaped the debate over the bomb and how historians approached it. Before the book appeared, few scholars took seriously the argument that political objectives had played a vital role in the decision to use the bomb. After it appeared, a broad consensus viewed diplomatic considerations as an important part of the administration's view of the bomb's value. This would have been inconceivable before Atomic Diplomacy. The book redirected the focus of questions that scholars asked about the bomb. The major issue was no longer whether the bomb was necessary to end the war as soon as possible. Rather the central questions had become: what factors were paramount in the decision to use the bomb and why was its use more attractive to policymakers than other alternatives? The best historical scholarship on the subject drew on a rich lode of recently opened sources, including the diary of Henry L. Stimson, the records of the Manhattan Project, the papers and diary of Joseph Davies, the notes of Byrnes's aide Walter Brown, and portions of the Roosevelt and Truman papers, to address those questions.

Scholars working on the subject did not offer unqualified comfort either to supporters of or detractors from Alperovitz's point of view. They sharply criticized his thesis in some respects, especially his emphasis on the "strategy of delay," the primacy of diplomatic goals, and the carefully plotted coherence of the Truman administration's policies. In general, they found that Alperovitz had exaggerated the impact of the bomb on the thinking of American leaders. But most scholars still subscribed to important elements of his interpretation, especially his claims that the bomb influenced American attitudes toward the Soviet Union and that diplomatic considerations played a role in deliberations on using the bomb against Japan.

\footnotetext{
${ }^{9}$ John Lewis Gaddis, The United States and the Origins of the Cold War, 1941-1947 (New York, 1972); Daniel Yergin, Shattered Peace: The Origins of the Cold War and the National Security State (Boston, 1977); Robert J. Donovan, Conflict and Crisis: The Presidency of Harry S. Truman, 1945-1948 (New York, 1977); Gregg Herken, The Winning Weapon: The Atomic Bomb in the Cold War, 1945-1950 (New York, 1980); Robert L. Messer, The End of an Alliance: Jomes F. Byrnes, Roosevelt, Truman and the Origins of the Cold War (Chapel Hill, 1982).
} 
At that point, despite differences of opinion over some specific issues, the historiographical debate over the bomb seemed largely settled. The latest scholarship combined the traditional view that the United States dropped the bomb primarily for military reasons with the revisionist assertion that its inclusion in America's diplomatic arsenal aggravated tensions with the Soviet Union. The consensus did not go unchallenged for long, however. Important new evidence-Truman's handwritten diary notes of the Potsdam Conference, which were published in 1980, and private letters he had written to his wife, which were published in 1983-prompted a reexamination of some important questions.

Truman's diary notes and letters provided the best available evidence about his understanding of and thoughts on the implications of the bomb at the time of Potsdam. But the new materials did not offer clear answers to the questions that had intrigued scholars. Indeed, as Robert Messer pointed out in a special issue of the Bulletin of the Atomic Scientists on the fortieth anniversary of Hiroshima, their implications for the historiographical debate over the use of the bomb were decidedly ambivalent. For example, after meeting with Joseph Stalin for the first time, Truman recorded in his diary that the Soviet premier promised to enter the war against Japan on 15 August 1945, and added: "Fini Japs when that comes about." Here, then, was striking testimony that the president knew that the bomb was not needed to end the war quickly. This and other notations supported Alperovitz's contention that military requirements were not the primary reasons for using the bomb. ${ }^{10}$

But as Messer suggested, other statements Truman made seemed "to disprove the revisionist contention that he did not want 'the Russians' in the war at all." For a time, the president continued to express hope that the Soviets would enter the war promptly, which appeared to contradict the claim that one purpose of dropping the bomb was to keep the Soviets out of the war. This discrepancy can be resolved by the fact that Truman and his advisers decided shortly after learning details about the power of the bomb tested in New Mexico that Soviet entry into the war was neither necessary nor desirable.

Yet other Truman statements in his diary and his letters from Potsdam raise further questions about his views. He told his wife on $18 \mathrm{July}$ (before receiving details about the test shot): "I've gotten what I came for-Stalin

\footnotetext{
${ }^{10}$ Robert L. Messer, "New Evidence on Truman's Decision," Bulletin of the Atomic Scientists 41 (August 1985): 50-56. The diary notes are printed in Eduard Mark, "Today Has Been a Historical One: Harry S. Truman's Diary of the Potsdam Conference," Diplomatic History 4 (Summer 1980): 317-26; Barton J. Bernstein, "Truman at Potsdam: His Secret Diary," Foreign Service Journal 57 (July/August 1980): 29-36; and Robert H. Ferrell, ed., Off the Record: The Private Papers of Harry S. Truman (New York, 1980). Ferrell made no comment on the implications of the diary for the debate over the use of the bomb, but he did suggest that it provided evidence of duplicity on the part of Stalin. See Ferrell, ed., "Truman at Potsdam," American Heritage 31 (June/July 1980): 36-47. Truman's letters to his wife are published in Robert H. Ferrell, ed., Dear Bess: The Letters from Harry to Bess Truman, 1910-1959 (New York, 1983).
} 
goes to war August 15 with no strings on it." He added: "I'll say that we'll end the war a year sooner now, and think of the kids who won't be killed!" Did Truman at that time really believe that the war could last another year? If so, in contrast to other of his comments, it could support the traditional argument that his principal motive for using the bomb was to shorten the war. But on the same day that the president wrote to his wife about ending the war a year early, he recorded in his diary: "Believe Japs will fold before Russia comes in. I am sure they will when Manhattan appears over their homeland." This seems to suggest that Truman saw the bomb as a way not only to end the war sooner than expected but also to keep the Soviets out of it. The Truman documents are fascinating but inconclusive and sometimes contradictory. As Messer pointed out: "The evidence of the Potsdam diary and letters does not close the book on the question of why the bomb was dropped. Rather it opens it to a previously unseen page."11

If Truman's notes and letters muddied the historiographical waters, three books published around the fortieth anniversary of Hiroshima did little to clear them. Each was written by a professional journalist who regretted the use of the bormb but did not directly address the issues debated by historians. The best of them was Richard Rhodes's The Making of the Atomic Bomb, which focused on the scientific and technical complexities that had to be overcome to build an atomic bomb. Rhodes delivered an absorbing narrative of the problems and personalities involved in the Manhattan Project but discussed the decision to drop the bomb only briefly. He maintained that once the weapon proved successful, "men discovered reasons to use it." In a brutal and barbaric war, the very existence of the bomb assured that it would be used without much thought of the long-range policy or human consequences. In Day One, Peter Wyden placed the primary burden for Hiroshima on the atomic scientists who plunged ahead with work on the bomb despite its potential dangers and the threat it posed to postwar peace. He largely absolved policymakers of ultimate responsibility for using the bomb because he believed that they were incapable of understanding the scientific principles or long-term political implications of nuclear weapons. Since Truman and his advisers were unable to control the speed or direction of events, the existence of the bomb guaranteed its use. In Day of the Bomb, Dan Kurzman described the developments leading to Hiroshima in a series of personality vignettes that never came together to form a thesis. ${ }^{12}$

Unlike Rhodes, Wyden, and Kurzman, Gar Alperovitz showed no reluctance to deal explicitly with historiographical issues. In an updated edition of Atomic Diplomacy published in 1985, he struck back at his critics. He dismissed Rose's work, and although both Sherwin's and Bernstein's conclusions were more to his liking, he still found them

\footnotetext{
${ }^{11}$ Messer, "New Evidence on Trurnan's Decision," 55-56; Ferrell, Off the Record, 5354; idem, Dear Bess, 519.

${ }^{12}$ Richard Rhodes, The Making of the Alomic Bomb (New York, 1987); Peter Wyden, Day One: Before Hiroshima and After (New York, 1984); Dan Kurzman, Day of the Bamb: Coundown to Hiroshima (New York, 1986).
} 
objectionable in important respects. Alperovitz contested their emphasis on the weight of Roosevelt's legacy in limiting Truman's options. He argued that the changing situation in Japan gave Truman wide latitude to revise policies he inherited from Roosevelt, and furthermore, that the president realized that the bomb was not necessary to end the war because a number of prominent advisers, including chief of staff William D. Leahy, General Dwight D. Eisenhower, and Undersecretary of the Navy Ralph Bard, told him so. Reaffirming his belief in a "strategy of delay," and in the possibility of ending the war on favorable terms without the bomb, Alperovitz challenged the view that the United States dropped it primarily for military reasons. He insisted that there was no "overriding military necessity" for the bomb and that Truman and his closest aides knew it. Therefore, in his estimation, only the desire to impress the Soviets and to achieve diplomatic objectives could explain why Truman disdained alternatives to end the war and hastened to use the bomb. In short, after considering the new evidence and interpretations of other scholars, Alperovitz altered his opinions of twenty years earlier very little. In fact, the only changes he said he would make in his first edition would be to place greater stress on Bymes's role in atomic policymaking and to move material originally located in an appendix into the main body of text. ${ }^{13}$

While Alperovitz was reasserting the correctness of his own position, other scholars were reexamining a number of old issues in the light of new evidence and arriving at some fresh conclusions. One such question was whether the bomb was necessary to save large numbers of American lives. Although several writers had addressed this matter by suggesting that the war could have ended and the loss of life averted without the bomb, new sources indicated that even in the worst case U.S. casualties would have been far fewer than former policymakers asserted after the war. In explaining why the United States had dropped the bomb, Truman and others argued that an invasion of the Japanese islands could have caused one-half million American deaths. But Rufus E. Miles, Jr., pointed out in an article published in 1985 that during the war military planners never projected casualty figures that were even close to those cited by Truman after the war. Even in the unlikely event that an invasion had been necessary, the presurrender estimates did not exceed twenty thousand. Barton J. Bernstein, drawing on recently opened records, found the worst-case prediction to be a loss of forty-six thousand lives, still far short of the policymakers' claims. "The myth of the 500,000 American lives saved," he concluded, "thus seems to have no basis in fact."14

${ }^{13}$ Gar Alperovitz, Atomic Diplomacy: Hiroshima and Potsdam, rev. ed. (New York, 1985). Barton J. Bemstein argued that Eisenhower did not object to using the bomb against Japan in "Ike and Hiroshima: Did He Oppose It?" Journal of Strategic Studies 10 (September 1987): 377-89.

${ }_{14}$ Rufus E. Miles, Jr., "Hiroshima: The Strange Myth of Half a Million American Lives Saved," International Security 10 (Fall 1985): 121-40; Banton J. Bemstein, "A Postwar Myth: 500,000 U.S. Lives Saved," Bulletin of the Atomic Scientists 42 (June/July 1986): 38-40. In brief discussions of the same issue Martin J. Sherwin and Michael S. Sherry have offered support for the view set forth by Miles and Bernstein. See Sherwin, A World 
The sparing of forty-six thousand or twenty thousand or many fewer lives might well have provided ample justification for using the bomb, but Truman and other high-level officials did not choose to make a case on those grounds. For some reason they felt compelled to exaggerate the estimated casualties greatly. Bernstein speculated that Truman felt more ambivalent about dropping the bomb than he ever admitted. This would explain, he argued, not only the need to inflate the number of lives saved by the bomb but also Truman's apparent self-delusion that it had been used on "purely military" targets. Robert L. Messer also addressed the intriguing question of Truman's state of mind regarding the bomb. He suggested that even though the president never acknowledged any feelings of remorse, he harbored a heavy burden of guilt arising from the discrepancy between the mass slaughter of civilians and his own moral convictions. ${ }^{15}$

The observations of Bernstein and Messer on Truman's inner conflicts added a new dimension to what was always a key, though often unstated, issue in the debate over the bomb: was its use morally justified? This is, of course, a highly subjective judgment that has usually been implied more than explicitly discussed. If, as the defenders of the Truman administration maintained, the bomb shortened the war and saved lives, the morality of its use is defensible. But if, as many critics suggested, the bomb was not needed to end the war or to save lives, then its morality seems highly questionable. Some writers sidestepped this dichotomy by arguing that war is inherently immoral and that the atomic bombs were no more heinous than the firebombs and napalm that killed tens of thousands of civilians before Hiroshima. The moral desolation of the Pacific war was graphically illustrated by John Dower's War without Mercy, which described the atrocities carried out by both sides and reconstructed the cultural context in which the bomb was used. Dower showed that Americans viewed the Japanese as depraved, contemptible, apelike subhumans, or alternatively, as fanatical, ruthless, and cruel superhumans. Although he said little about the bomb, it seems clear that both images he depicted discouraged open-minded consideration of the moral implications of using it. ${ }^{16}$

The moral aspects of the use of the bomb were addressed more thoroughly and directly in two studies of American strategic bombing policy during World War II. Ronald Schaffer traced the evolution of bombing theory and practice from the precision strikes of the early war to the indiscriminate bombing of cities by the end of the war. The atomic attacks on Hiroshima and Nagasaki were a logical extension of the rationales developed for terror bombing with conventional weapons. Schaffer found that American leaders

Destroyed: Hiroshima and the Origins of the Arms Race, rev. ed. (New York, 1987); and Sherry, The Rise of American Air Power: The Creation of Armageddon (New Haven, 1987).

${ }^{15}$ Bernstein, "A Postwar Myth," 40, and "Truman at Potsdam," 32; Roben L. Messer, "America's 'Sacred Trust': Truman and the Bornb, 1945-1949," paper presented at the annual meeting of American Historical Association, 1987.

16 John W. Dower, War withoul Mercy: Race and Power in the Pacific War (New York, 1986). 
and scientists weighed the moral issues involved in the use of the atomic bomb. With the exception of the removal of the ancient city of Kyoto from the target list, however, he submitted that "moral constraints in the hearts and minds of those responsible for the American air war do not seem to have prevented them from employing any of the measures they contemplated using against Japan." Michael S. Sherry agreed that use of nuclear bombs could only be understood in the context of previous U.S. strategic policies. Although the moral aspects of American bombing were not the central theme of his book as they were with Schaffer's, they were an important and vivid part of it. Sherry suggested that scholars had focused too narrowly on the "sin of atomic bombing," which, "like the sin of the whole war's bombing," resulted from "a slow accretion of large fears, thoughtless assumptions, and incremental decisions." 17

Assessing the moral implications of the bomb inevitably leads to examining the possible alternatives to it. Several scholars have raised anew the question of why the administration did not pursue, or even explore, other options. One was to modify the demand for unconditional surrender and give clear assurances to the Japanese that they could retain the emperor. Sherry contended that the failure to do this was "the most tragic blunder in American surrender policy." Although he acknowledged that such an offer would not have guaranteed an immediate Japanese surrender, he argued that the risks were small and the "moral risks ... in pursuing an atomic solution... were large." Sherry did not view the refusal to soften unconditional surrender and the decision to drop the bomb as an effort to achieve political goals, however. He saw the use of the bomb as an outgrowth of momentum, confusion, and the "technological fanaticism" that had overtaken American bombing policy. ${ }^{18}$

In his comments on Paul Fussell's essay, Martin J. Sherwin criticized the Truman administration even more severely than Sherry and, indeed, more sharply than in his own A World Destroyed. He suggested that Truman rejected the idea of modifying the unconditional surrender terms partly for domestic political reasons and partly because "he preferred to use the atomic bomb" to strengthen America's diplomatic position. He further maintained that by electing to wait for the bomb Truman prolonged the war; it might have ended sooner if the president had moderated the demand for unconditional surrender. Kai Erikson briefly explored another alternative to dropping the bomb on a densely populated city. He examined the question of why the United States did not fire a warning shot by dropping the bomb on a "relatively uninhabited"-Japanese target. This would have given enemy leaders a graphic display of what would happen if they did not surrender promptly. The risks of this kind of demonstration were minimal; if it did not work other bombs could still be used on the cities on the target list. Erikson was troubled that neither this nor any other option received serious

${ }^{17}$ Ronald Schaffer, Wings of Judgment: American Bombing in World War II (New York, 1985); Sherry, Rise of American Air Power, 301-41, 363.

${ }^{18}$ Sherry, Rise of American Air Power, 255, 301-56. 
consideration from American policymakers. He attributed their aversion to alternatives to a number of military and political factors, the most important of which was "the wish to make a loud announcement to the Russians." 19

In a book he published forty years after coauthoring Henry L. Stimson's memoirs, McGeorge Bundy disagreed that the bomb's potential impact on the Soviet Union was a major factor in its use. But he too lamented that the highest officials in the Truman administration did not carefully weigh alternatives to the bomb; he acknowledged that Stimson had overstated the extent to which the administration considered other options. In yet another twist on this theme, Bundy suggested that if the United States had admitted respected neutral observers to the successful atomic test shot at Alamogordo, New Mexico, they might have provided a convincing and effective warning to the Japanese about the power of the bomb. While a number of scholars reopened questions about alternatives to the bomb and faulted the Truman administration for not pursuing them, Akira Iriye argued that the Japanese government shared the blame for needlessly extending the war. He was particularly critical of Japanese leaders for sending peace feelers to the Soviet Union rather than attempting to deal directly with the United States. ${ }^{20}$

Barton Bernstein took issue with those who argued that the war could have ended as soon or even sooner than it did without using the bomb. He suggested that it was unlikely that the alternatives available to U.S. policymakers-demonstrating the bomb in an isolated location, modifying the unconditional surrender demand, exploring the initiatives of Japanese peace feelers, waiting for Soviet entry into the Asian war, or intensifying conventional bombing-would have brought the war to a conclusion as rapidly as dropping the bomb. He doubted that any of the alternatives, taken alone, would have been sufficient to force a prompt Japanese surrender, and he maintained that even a combination of them might not have ended the war before 1 November 1945. Bernstein's disagreement with other scholars over the role of the bomb in determining how quickly the war came to a close was necessarily speculative, and the question is unlikely to reach a definitive resolution. But it resurrected a historiographical debate that had seemed to be settled: was the bomb necessary to end the war as soon as possible and save substantial numbers of American lives? ${ }^{21}$

One other issue that recent scholarship has revisited is whether or not the United States practiced atomic diplomacy. This is primarily a postwar question, and a discussion of the extent to which the Truman administration used its atomic monopoly for diplomatic purposes after Hiroshima extends far beyond the scope of this essay. But Melvyn P. Leffler suggested that even

\footnotetext{
${ }^{19}$ Sherwin, "Hiroshima and Modem Memory," 352; Kai Erikson, "Of Accidental Judgments and Casual Slaughters," Nation 241 (3/10 August 1985): 80-85.

${ }^{20} \mathrm{McGeorge}$ Bundy, Danger and Survival: Choices about the Bomb in the First Fifty Years (New York, 1988); Akira Iriye, Power and Culture: The Japanese-American War, 1941-1945 (Cambridge, MA, 1981).

${ }^{21}$ Barton J. Bernstein, "The Atomic Bomb and the Japanese Surrender: Missed Opportunities and Missed Disasters," in Hiroshima after Forty Years, ed. I. B. Holley (forthcoming).
} 
before the end of the war, the possession of the bomb influenced American foreign policy on one important matter. He argued that after learning about the power of the bomb, the administration not only lost interest in Soviet entry into the Asian war but also repudiated the sections of the Yalta agreement dealing with the Far East. "At the time of Japan's surrender," he wrote, "Stalin had more reason to question the American desire to comply with Yalta's Far East provisions than vice versa."22

Although recent analyses of the use of the bomb have raised probing questions, the answers they provided have often been tentative and suggestive. They have unsettled the historiography of the subject without redefining it or offering new directions that might clarify outstanding issues. Leon V. Sigal's Fighting to a Finish, published in 1988, did a little of both. By looking at the decision to drop the bomb from the perspective of bureaucratic politics, Sigal presented answers to some of the questions that had puzzled other scholars. The problem with existing studies, Sigal submitted, was that they took a "rational choice approach" to understanding why the bomb was dropped. He maintained that this approach, which assumed that "national interests motivate state action," could not explain the inconsistent and sometimes irrational policies followed by both the United States and Japan. The best way to unravel those mysteries was by looking at bureaucratic politics and organizational process on both sides. Sigal's analysis was less original than he claimed; other scholars had called attention to differing views within the American and Japanese governments. But his systematic discussion of bureaucratic factors produced some fresh insights into the use of the bomb.

Sigal suggested that the reason that Japanese leaders did not make direct contact with the United States, a point that Iriye raised, was that bitter factional rivalry prevented it. Army opposition foreclosed direct peace initiatives, so Japanese leaders seeking to end the war were limited to clandestine approaches in Moscow. "It was," Sigal wrote, "Moscow or nowhere for Japan's diplomats." The same kind of forces often, but not always, influenced American actions. Sigal depicted the effort to relax the unconditional surrender terms as a victim of domestic politics. Stimson, Undersecretary of State Joseph Grew, and other high officials urged the president to allow the Japanese to keep the imperial institution, but Truman and Byrnes feared the political consequences of doing so.

In other decisions, however, Sigal found bureaucratic politics to be paramount. He portrayed top American officials as largely powerless, ineffective, and ill-informed. Truman was too inexperienced and insulated to grasp fully what was going on; his de facto authority was limited to halting the use of the bomb if he chose. But he had no compelling reason to do so. The key decisions on targeting and timing were made not by the president or the secretary of war but by General Leslie R. Groves and other military

${ }^{22}$ Melvyn P. Leffler, "From Accommodation to Containment: The United States and the Far East Provisions of the Yalta Agreements," in Yalta: Un Mito Che Resiste [Yalta: a myth that endures], ed. Paola Brunda Olla (Rome, 1989). 
commanders. Groves, especially, was anxious to justify the effort and the expenditures of the Manhattan Project, and he avoided outlining alternatives to Truman that could change existing plans and frustrate his objectives. Thus the bomb fell more because of bureaucratic imperatives than because of carefully considered questions of national interest. Weighing alternatives to bombing Japanese cities or seeking viable ways to reach Japanese peace advocates never received attentive review by the president or his closest advisers. ${ }^{23}$

Sigal's interpretation offered plausible answers to some important questions. It explained why the Japanese were so circumspect in their peace initiatives, why the United States did not pursue alternatives to the bomb, and why Truman often seemed so confused about issues relating to the bomb. Although much of the information he presented was well known, he offered a new and useful interpretive framework for it. But his interpretation was hardly definitive. It failed to show why Truman and other top policymakers did not act to assert greater control over decisions about the bomb or to overrule their subordinates. The ultimate authority remained at the top; historians still need to sort out what was critical and what was not in the thinking of key officials. And as Sigal made clear in his discussion of the internal debate over unconditional surrender, bureaucratic politics were not always the determining factor in decision making.

Careful scholarly treatment of the records and manuscripts opened over the past few years has greatly enhanced our understanding of why the Truman administration used atomic weapons against Japan. Experts continue to disagree on some issues, but critical questions have been answered. The consensus among scholars is that the bomb was not needed to avoid an invasion of Japan and to end the war within a relatively short time. It is clear that alternatives to the bomb existed and that Truman and his advisers knew it. In light of Fussell's essay and the large number of letters he received from World War II veterans who "cheered themselves hoarse" in support of his argument, it bears repeating that an invasion was a remote possibility. ${ }^{24}$ Whether the bomb shortened the war and saved lives among those who were fighting in the Pacific is much more difficult to ascertain. Some analysts have argued that the war would have ended just as soon, or even sooner, if American leaders had pursued available alternatives, but this is speculative and a matter of continuing debate. It is certain that the hoary claim that the bomb prevented one-half million American combat deaths is unsupportable. The issue of whether the use of the bomb was justified if it spared far fewer American lives belongs more in the realm of philosophy than history. But there are tantalizing hints that Truman had some unacknowledged doubts about the morality of his decision.

Since the United States did not drop the bomb to save hundreds of thousands of American lives, as policymakers later claimed, the key question

${ }^{23}$ Leon V. Sigal, Fighting to a Finish: The Politics of War Termination in the United States and Japan, 1945 (Thaca, 1988).

${ }^{24}$ Fussell, Thank God for the Atom Bomb, 45. 
and the source of most of the historiographical debate is why the bomb was used. No scholar of the subject accepts in unadulterated form Alperovitz's argument that political considerations dictated the decision. But nearly all students of the events leading to Hiroshima agree that, in addition to viewing it as the means to end the war quickly, the political implications of the bomb figured in the administration's deliberations. The consensus of the mid1970 s, which held that the bomb was used primarily for military reasons and secondarily for diplomatic ones, continues to prevail. It has been challenged and reassessed in some of its specific points. But the central theme in the consensus that has existed for the past dozen years-that U.S. officials always assumed that the bomb would be used and saw no reason not to use it once it became available-remains intact. There were no moral, military, diplomatic, or bureaucratic considerations that carried enough weight to deter dropping the bomb and gaining its projected military and diplomatic benefits.

Since the mid-1970s, when the contention between traditional and revisionist views of why the United States used the bomb was largely resolved, scholarship on the subject has not divided into discrete or discernible schools of interpretation. Within the broad consensus that currently prevails, there is ample room for disagreement and differing emphases. This is clear in the interpretations offered in two general studies, one in the context of the end of the war with Japan and one in the context of the beginning of the nuclear age. Ronald $\mathrm{H}$. Spector, in a study of the American-Japanese conflict, acknowledged that the administration recognized that the bomb would have political advantages but contended that the use of both atomic weapons was necessary to shock the Japanese into surrender. In a book on the history of nuclear energy, Gerard H. Clarfield and William M. Wiecek argued that the momentum of the long-standing assumption that the bomb would be used and the desire to hasten the end of the war doomed Hiroshima, but they placed greater stress on diplomatic objectives than Spector. They regretted that Truman and his advisers did not explore alternatives to the bomb. "By using nuclear weapons in combat," they asserted, "the Truman administration established the principle that though genocidal they were legitimate."25

Despite the volume and the variety of work on the decision to drop the bomb, a few issues merit more attention than they have received. One concerns the meaning of the test explosion of the first nuclear device (it was not, strictly speaking, a bomb) at Alamogordo. The consequences of the Trinity shot in symbolic and scientific terms is clear enough, but its significance for policy is less so. The test was made to prove the design of a weapon fueled with plutonium and detonated by an intricate system of implosion, which was one of two different bombs being built in Los Alamos. The effectiveness of this method was in doubt until the experimental explosion lighted the New Mexico sky. But the atomic

${ }^{25}$ Ronald H. Spector. Eagle against the Sun: The American War with Japan (New York, 1985); Gerard H. Clarfield and William M. Wiecek, Nuclear America: Military and Civilian Nuclear Power in the United States, 1940-1980 (New York, 1984). 
scientists were much more certain that the other design, a gun-type method in which one subcritical mass of highly enriched uranium- 235 was fired at another, would succeed. Groves told Truman in their first meeting about the Manhattan Project in April 1945 that the uranium bomb would be ready without requiring a test around 1 August, and despite some qualms, scientists remained confident that it would work. Their confidence was justified-it was a uranium bomb that destroyed Hiroshima. This suggests that the Trinity test, for all its symbolic meaning, need not have been crucial to policymaking.

If Truman and his advisers realized during the summer of 1945 that the uranium bomb was almost ready and almost certain to work, it is curious that they reacted with so much surprise and elation to the news of the Trinity shot. If they did not understand that they would soon have an atomic bomb no matter what happened at Alamogordo, it suggests that they grasped or remembered little of what they were told about the details of the bomb project. Part of the explanation is that policymakers did not want to rely on the bomb until it definitely had proven to be successful, and they were unwilling to believe that it would make a major difference to them until they were shown what it could do. But they seemed to have little awareness that two types of bombs were being built. Even Stimson, the best-informed and most reflective senior official on matters regarding the bomb, appeared to think in terms of a single weapon that had to be tested at Alamogordo. ${ }^{26}$ The issue is not one of transcending importance, but it could help to clarify the significance that Truman and his advisers attached to the bomb and its role in their planning. It might in that way resolve some of the contradictions and apparent confusion in Truman's diary.

Another subject that could benefit from further study is the role of scientists in the Manhattan Project. The ideas and activities of the atomic scientists, individually and corporately, have hardly suffered from neglect. Several scholars have offered detailed accounts, particularly of the outspoken dissent of some of the Chicago scientists who wanted alternatives to the bomb explored and an approach to the Soviets seriously considered. The concems of the scientists had no discernible impact on policy, which has led some scholars to reproach policymakers for failing to heed the warnings of the experts and others to chide the scientists for failing to press their views more effectively. Richard Rhodes and Peter Wyden have recently reexamined the activities of the atomic scientists and raised, implicitly and explicitly, a number of difficult but important questions. What were the motivations of atomic scientists in building the bomb? Was their quest to prove their theories about the atom socially and politically irresponsible? Did they fail to provide moral leadership commensurate with their scientific leadership? What precisely was the relationship between the policies being framed in Washington and the process of building the bomb in Los Alamos? And

${ }^{26}$ Sherwin, A World Destroyed, 3-6: Stimson and Bundy, On Active Service in Peace and War, 618, 637 . 
what, if any, were the political and moral obligations of the scientists involved in the bomb project? ${ }^{27}$

Some of the atomic scientists who worked on the Manhattan Project have expressed remorse that their technical achievement produced such dreadful consequences, real and potential. Joseph Rotblat, who left Los Alamos in late 1944 after learning that Nazi Germany had no atomic bomb, recently reflected about why more of his colleagues did not do the same when it became clear that the original incentive for racing to build the bomb had been removed. He cited three reasons: scientific curiosity, a desire to hasten the end of the Pacific war, and fear of hurting their professional opportunities. The majority of atomic scientists he knew, Rotblat concluded, "were not bothered by moral scruples." He was perhaps too harsh in his judgments, but the issues he raised are important. What was the proper role of scientists, whether or not they had moral scruples, in designing weapons of mass destruction? Were atomic scientists sedated by an assumption that their spokesmen or political leaders would have the foresight, wisdom, and power to control atomic energy once it became a reality? ${ }^{28}$

Another topic that deserves further attention is the role of the Russian bomb project in Soviet-American relations at the close of the war. Historical writing has focused on the effects of the American bomb on the deteriorating Grand Alliance, and information on the Soviet effort to build a bomb is still sketchy. What is known is intriguing, and, as might be expected, historiographically controversial. David Holloway, in one view of the Soviet bomb project, suggested that even if Truman had been more forthright in notifying Stalin about the Trinity shot at Potsdam, Soviet policies might have been the same. "But," he added, "Western secrecy contributed to Soviet suspicion and spurred the Soviet Union to develop its own bomb."29

Walter A. McDougall offered a different interpretation in a book on the space race. He described the Soviet Union as the original "technocracy," a nation in which technology was "a cold tool of the state." In a brief discussion of the Soviet atomic project, McDougall suggested that the bomb was an inevitable product of the Soviet system. If he is right, then the debate over how the use of the bomb affected Soviet-American relations must be critically reexamined. If the Soviets were immutably committed to

${ }^{27}$ Sherwin, Wyden, and Rhodes, cited above; and Alice Kimball Smith, A Peril and a Hope: The Scientists' Movement in America, 1945-1947 (Chicago, 1965), portrayed the views of dissenting scientists sympathetically. Brian Loring Villa chided them for waiting too long to try to register their doubts about using the bomb with policymakers. See "A Confusion of Signals: James Franck, the Chicago Scientists, and Early Efforts to Stop the Bomb," Bulletin of the Atomic Scientists 31 (December 1975): 36-43.

${ }^{28}$ Joseph Rotblat, "Leaving the Bomb Project," Bulletin of the Atomic Scientists 41 (August 1985): 16-19. For other useful discussions of the views of scientists see Martin J. Sherwin, "How Well They Meant," Victor F. Weisskopf, "Looking Back on Los Alamos," Robert R. Wilson, "Niels Bohr and the Young Scientists," and Rudolf Peierls, "Reflections of a British Participant," in ibid., 9-15, 20-29.

${ }^{29}$ David Holloway, The Soviet Union and the Arms Race (New Haven, 1983); Robert Chadwell Williams, Klaus Fuchs: Alom Spy (Cambridge, MA, 1987); Tad Szulc, "The Untold Story of How Russia 'Got the Bomb,' " Los Angeles Times, 26 August 1984. 
developing nuclear weapons, an attempt on the part of the United States to practice atomic diplomacy would have made little or no difference in their determination to build the bomb, though it might have in the urgency with which they proceeded and in their diplomatic posture. McGeorge Bundy added another perspective to this subject by submitting that even though Stalin's decision to build the bomb was irreversible, he was not inalterably opposed to negotiation of atomic issues. But of necessity, Bundy provided little evidence to support his view that a sincere and unqualified diplomatic approach to the Soviets might have been fruitful. In any event, the issue of atomic diplomacy will remain open until a better picture of Soviet atomic policies and progress emerges. ${ }^{30}$

The outpouring of books and articles on the use of the bomb in the past several years was at least in part spurred by the fortieth anniversary of Hiroshima and by profound concern about the nuclear policies of President Ronald Reagan. The latest literature has expanded and enriched our knowledge of the decision to use the bomb while at the same time raising new questions. The consensus that emerged in the mid-1970s still prevails, but it has been and surely will continue to be tested and reappraised. The events that led to Hiroshima are so innately interesting, so vital to understanding subsequent developments, so politically and morally ambiguous, and so much a part of popular mythology that it seems certain that they will perpetually occupy the attention of and stir discord among scholars of World War II and the nuclear age.

${ }^{30}$ Walter A. MacDougall, ...The Heavens and the Earth: A Political History of the Space Age (New York, 1985); Bundy, Danger and Survival, 179-82. 